\title{
Archdeacon Sebastian Barbu-Bucur PhD - Researcher of the Byzantine Musical Tradition across the Romanian Territory
}

\author{
ELENA CHIRCEV \\ “Gheorghe Dima” Music Academy of Cluj-Napoca \\ ROMANIA*
}

\begin{abstract}
Professor Archdeacon Sebastian Babu-Bucur PhD is one of the most prominent representatives of Romanian Byzantology with a tireless activity spreading throughout different fields - research, psalmic musical creation, teaching, performing. Our study focuses briefly on several of the researcher's achievements, some of his main concerns having been the Romanianisation process of the church chant in the $18^{\text {th }}$ century and the manuscripts elaborated by Romanians. We highlighted the merits of the Byzantinist musicologist who contributed to the discovery of most of the Romanian manuscript no. 61 in the Romanian Academy Library, who tracked down and catalogued over 250 Romanian manuscripts to be found in the libraries from Mount Athos, who demonstrated through documenta and transcripta editions the significance of the activity of various Romanian psalm readers whose contribution to the translation of chants in Romanian had been, up to that moment, almost unknown. Archdeacon Sebastian Babu-Bucur's tireless work as a researcher of Byzantine music contributes to a better knowledge and understanding of the evolution of this type of music in the $18^{\text {th }}$ and the $19^{\text {th }}$ century and leads the way towards new investigations in the years to come.
\end{abstract}

Keywords: Filothei, Ghelasie, Mihalache, Mount Athos, the Romanianisation process.

\section{Introduction}

Archdeacon Professor Sebastian Barbu-Bucur PhD is one of the most renowned representatives of the Romanian byzantine musicology of the second half of the $20^{\text {th }}$ century and of the early $21^{\text {st }}$ century. His activity stands out due to its abundance and diversity. He is an esteemed researcher of the musical manuscripts related to the process of Romanianisation of the Orthodox Church music, as well as a distinguished teacher, a performer and a promoter of this music by means of the Psalmodia band whose fonder and conductor he was (Chircev, 2013).

The studies and volumes that he printed in the last 35 years represent a precious and useful bibliography for those who approach topics related to the music of Byzantine tradition dating from the $18^{\text {th }}$ and the $19^{\text {th }}$ century, to the Romanian musical manuscripts to be found at the Holy Mount Athos or for

\footnotetext{
*elena_chircev@yahoo.co.uk
} 
those who are interested in the activity of certain eminent representatives of the psalmic music from across the Romanian Principalities.

\section{Biographical Premises of his Activity as Researcher and Performer of Music of Byzantine Tradition}

Father Sebastian Barbu-Bucur's approach to such a peculiar field as the one of the Byzantine musical paleography resides in his profound passion for music, noticeable even in childhood. Born in the county of Prahova, more specifically in Talea ${ }^{1}$, on the $6^{\text {th }}$ of February 1930, in a peasant family strongly anchored in the Christian values ${ }^{2}$, the future researcher (by the secular name of Stelian) was enchanted by the universe of sounds due to the psalmic music that he learned ever since he was a child from the priest from his hometown. That is why the first two decades of young Stelian's life were characterised by the activity in three monasteries, two of which played a special role within the framework of the music of Byzantine tradition. Gifted with visible musical skills $^{3}$, he was advised to study music so, at the age of 11 , he was already a pupil with the School of Chanters of the Căldăruşani Monastery (1941-1945) ${ }^{4}$, a well known monastic settlement of the time due to the high standards of the pupils' musical training. The period spent at the Theological Seminary from the Neamt Monastery ${ }^{5}$ (1948-1952), was also beneficial to the completion of his theoretical and performance-related knowledge of psalmic music ${ }^{6}$. In the meantime, he had joined the clergy at the Cheia Monastery from the County of Prahova and he had been given his monastic name, Sebastian (1950).

His student years (1953-1957) contributed to the fulfilment of his training as a theologist and as a future researcher of Byzantine music. The topic of his bachelor's thesis when he graduates from the Theological Institute with academic accreditation from Bucharest (1957) already points to the coordinates

\footnotetext{
${ }^{1}$ The township of Talea is located in the north-eastern part of the Prahova County.

2 Three of his sisters joined the clergy ever since they were young and his mother soon after she had become a widower (Chircev E., 2005 a).

${ }^{3}$ Father Sebastian would often evoke the moment when his teacher from primary school noticed his musical talent; at the time, the teacher was rehearsing a Christmas carol with the pupils when she noticed the spontaneous intonation of the second voice at a third. The teacher suggested to his family that he would be sent to a specialised school (Chircev E., 2005 a).

${ }^{4}$ Căldărușani Monastery is one of the biggest and oldest orthodox monasteries of Wallachia. It is located on the Căldărușani lake waterfront, near Bucharest. It was founded in 1638 by Matei Basarab (1632-1654).

${ }^{5}$ Neamț Monastery is an orthodox monk monastery located in the County of Neamț, the first documented mention dating from 1407. The clerical settlement has the biggest and oldest monastery library (18000 volumes) and it had a remarkable contribution to the development of Romanian art and culture. The premises also host the building pertaining to the "Veniamin Costache” Theological Seminary.

${ }^{6}$ Among his teachers from the seminary two important psalms readers are to be mentioned: Atanasie Dincă and Victor Ojog.
} 
of his future interests: The School for the Vocal Church Music of Buzău, Centre of Cultivation and Development of Psalmic Music for the Romanian People, the graduate himself confessing in the work: "ever since childhood I have noticed that my soul and my ear would vibrate for music, and especially for psalmic music, and this gave me the conviction that this love for artistic beauty could constitute the essence of my worldly existence and the path of my struggles towards redemption” (Chircev, 2005 a). Later on this inner impulse determined the young deacon, following the change of the political regime in Romania, to enroll in the "Ciprian Porumbescu" Music Conservatory of Bucharest (being expelled from the Neamt Monastery because of the 410/1959 decree, issued by the communist regime established in 1948).

Even though trained in the schools of Wallachia and Moldavia, the archdeacon Sebastian Barbu-Bucur PhD was affectionate to Cluj, the city where his efforts in respect to research peaked with the bestowal upon him of the title of Doctor of Musicology and Byzantology (1982), granted by the same higher education institution which, over the years, would recognise once more the merits of one of the most illustrious representatives of Romanian Byzantology by granting him the academic title of Doctor Honoris Causa (2005) - the "Gheorghe Dima” Music Academy of Cluj-Napoca.

Professor with the National University of Music Bucharest (1970-2005), Father Sebastian conducted for several decades an assiduous research of the musical manuscripts which he highlighted by publishing the hymns in photocopies and transcriptions, by studies and presentations within various scientific events. He instilled passion in regard to the research of these documents; he instilled it into his students and into the $\mathrm{PhD}$ students he guided and who continue researching and promoting the Byzantine music.

\section{Research related to the Romanian manuscript no. 61 - documentary attestation of the church chant in the Romanian language}

In June 2017 there was the celebration of 120 years from the first mention of the musical manuscript no. 61 to be found at the Romanian Academy Library of Bucharest ${ }^{7}$. Known by the name of "The Romanian Psalm Book", which was written on the title page by the author Filothei sin Aga Jipa - who signed his name on the last page mentioning the date of the completion of his exhaustive book (the $24^{\text {th }}$ of December 1713) - the manuscript was referred to in various articles and studies in the following decades by priests, historians and musicians ${ }^{8}$. However, it remained in everybody's memory only

\footnotetext{
${ }^{7}$ The mention belongs to Constantin Erbiceanu, see S. Barbu-Bucur (1989), Fl. Bucescu (1997, p. 149) and C. Catrina (2010, p. 67).

${ }^{8}$ The complete list of these mentions is to be consulted in Gheorghe C. Ionescu's work, Muzica bizantină în România. Dicționar cronologic, [The Byzantine music in Romania. Chronological dictionary], București: Editura Sagittarius, 2003, p. 447-483.
} 
due to Father Sebastian's hard work unfolding over a period of 25 years. The merit rests with Archdeacon Sebastian Barbu-Bucur PhD for having pointed out through longstanding and thorough research the importance of this manuscript - the oldest musical document of Byzantine tradition, with the text written in Romanian language by a Romanian for the Romanian people.

The Professor researched innumerable documents in public archives and libraries and he managed to clarify all the uncertainties regarding Filothei's ethnic origin, proving wrong the opinions expressed until his study. He established the Romanian origin and the genealogy of Filothei's family (the Jipa family) who was part of the Romanian nobility and was kindred with the families of the ruling figures Constantin Brâncoveanu and Șerban Cantacuzino. By corroborating information from various sources, he managed to outline a complete biography of the musician monk, he pointed out the complex training and the activity of translator of different papers printed at the beginning of the $18^{\text {th }}$ century ${ }^{9}$ which contributed to "the consolidation and unification of the Romanian literary language” (Barbu-Bucur, 1981, p. 42); he also emphasised Filothei's skills as composer of Catavasiilor Floriilor [The Flowers' Irmos of the 9 Canons] and of Rugăciunii lui Filothei pentru Constantin Brâncoveanu [Filothei's Prayer for Constantin Brâncoveanu].

The contrastive analysis of the musical content allowed him to identify the Greek sources of the chants from the manuscript as well as the manner in which the adaptation of the music to the Romanian language occurred. The illustrious researcher identified and studied the copies of the manuscript edited throughout the $18^{\text {th }}$ century, their existence being a proof of the dissemination and perpetuation of the chant in the Romanian language. Concurrently, relying on the documents he studied, he was able to determine the existence of Filothei's various apprentices who contributed to the transmission of this repertoire by means of didactic and chanter activity.

The manuscript was printed in four volumes which sum up to over 1800 pages and which include photocopies of the sheets of paper as well as the transcription of the chants onto a staff preceded by substantial introductory studies.

The valuable contribution brought to the Romanian musical world by the information discovered during research and the rectification of various errors related to the process of Romanianisation of church music, the significance of the volumes which offer study material to musicians - all this input was appreciated and it resulted in the author being granted, one by one (as the

9 Filothei translated three books which benefitted from a wide disseminaiton across the territory of Wallachia: Invățături creștinești (Snagov, 1700), Floarea darurilor (Snagov, 1700), Catavasier (Târgoviște, 1714). Archdeacon Sebastian Barbu-Bucur revealed the paternity of these works and highlighted their esteemed features. (Barbu-Bucur, 1981, pp. 2142). 
books were being edited) the awards of the Union of Romanian Composers and Musicologists (in the years: 1981, 1986, 1987, 1992). For his first volume he was also offered the "Ciprian Porumbescu" award of the Romanian Academy (1983) (Catrina C., 2005, p. 68).

\section{From Filothei's "Romanian Psalm Book" to the Romanianisation of church chants}

The thorough study of the manuscript dating from 1713 and of some of its adjacent features led the way towards a new research perspective. Another topic to which the Professor brought notable contributions was thus delineated, a topic of conspicuous importance for the knowledge and clarification of various aspects related to the perpetuation of the byzantine tradition in our country: the Romanianisation process of church chants. The investigation, undergoing mostly simultaneously with the one conducted on Filothei's manuscript, was synthesized in the PhD thesis ${ }^{10}$ published in 1989 by the title: Musical Culture of Byzantine Tradition across the Romanian Territory in the $18^{\text {th }}$ century and the Beginning of the $19^{\text {th }}$ century and the Original Contribution of the Local Culture (Barbu-Bucur, 1989). The work represents an original input in respect to the knowledge of the Romanian musical past, of psalmic education and of the Romanians who perpetuated the byzantine tradition. Documents of the age to be found in libraries, archives and museums, musical manuscripts and writings dating back to the Medieval Era brought to light or clarified the contribution of dedicated monks to a better knowledge and performance of church music in the Romanian language, bringing completion to and coherently outlining the Romanianisation process of church music unfolding over many centuries.

Even though the author's attention is directed towards the Romanianisation of the $18^{\text {th }}$ century church music which represents a substantial part of the volume, the book may be considered a first, concise attempt at presenting the history of Byzantine music across the Romanian territory; the first two chapters synthesize the information related to the Byzantine music across this territory up to the $18^{\text {th }}$ century, to psalmic education and the medieval musical grammars used in the schools for chanters; the final chapter illustrates the Romanian contributions to Mount Athos. The multitude of the documentary sources is impressive and so are the abundance and significance of the information provided, as well as the manner in which data is corroborated. The 1989 award from the Union of Romanian Composers and Musicologists represents an acknowledgment of the value and significance of this book which the composer Sigismund Toduță praised in the preface as an

\footnotetext{
10 The PhD thesis was presented at the "Gheorghe Dima” Music Academy of Cluj-Napoca in 1982, having Sigismund Toduță and Romeo Ghircoiaşiu as coordinators.
} 
"original" and "remarkable contribution" to the knowledge of medieval Romanian music "due to the chapters which unveil and synthesize historical and musical references, due to the inestimable value of the results obtained in the field of Byzantine palaeography” (Barbu-Bucur, 1989, p. 8).

\section{A dream come true: the catalogue of the Romanian musical manuscripts from Mount Athos}

Father Sebastian confessed in an interview for Radio Renaşterea ${ }^{11}$ : "I dearly wanted to go to Mount Athos in order to study the Byzantine musical manuscripts. It would often happen to me to dream that I had been there and I had found them"12 (Chircev, 2005 a). For some decades, the investigation of the documentary resources from the libraries at Mount Athos and the finding of the manuscripts elaborated by Romanians were not possible due to the strict surveillance regime the monks were under during the communist period. After a first trip (taken place with the support of the Union of Romanian Composers and Musicologists) destined for research, study and gathering information, in 1982 he was given the opportunity to access a study scholarship in Greece between 1983-1985 when he attended the $4^{\text {th }}$ and the $5^{\text {th }}$ year of his bachelor's study programme at the State Conservatory of Thessaloniki ${ }^{13}$. He was the first Romanian musicologist to walk the paths of the so-called "Garden of the Mother of God" after more than a century since Teodor T. Burada ${ }^{14}$ 's voyage to the Holy Mount Athos, as musicologist Viorel Cosma would note (Cosma, 1990).

Over the years, the project of tracking down the ancient Romanian codes to be found at Mount Athos came into being in the form of the volume entitled Romanian Musical Manuscripts from Mount Athos (Barbu-Bucur, 2000). The volume accounts for the diligent work unfolding over almost two decades in which he thoroughly described 253 musical manuscripts with Kukuzelian and Chrysanthic notation, manuscripts which had been elaborated by Romanian monks and had been discovered in the libraries of seven monasteries, hermitages and cells from Mount Athos. The catalogue drawn up by Father Sebastian is the first book of the kind to be printed in Romania and is to be

\footnotetext{
${ }^{11}$ Radio "Renașterea" is the radio station of the metropolitan church of the counties of Cluj, Sălaj and Maramureșului. In my capacity of producer of the "Byzantion" show, I organised an interview on the occasion of the Archdeacon's celebration of 75 years of age.

${ }^{12}$ Archdeacon Sebastian Barbu-Bucur refers to the manuscripts elaborated by Romanians.

${ }^{13}$ On his graduation, he received the "exceptional" rating and he was distinguished with the Acra Evareskeia diploma [High Appraisal].

14 Teodor T. Burada (1829-1923), Romanian musicologist, folklorist, ethnographer and historian, associate member of the Romanian Academy. He contributed to the discovery of the Cucuteni culture (between 5000 B.C. and 2750 A.D.). He wrote the $O$ călătorie la Muntele Athos [Journey to Mount Athos] brochure following his pilgrimage from 1884.
} 
praised for the way it points to the existence of various unpublished musical documents which could thus be brought to the attention of the Byzantine musicologists. Different Romanians who drew up manuscripts, composers, translators or copyists had their names discovered on the pages which had turned yellow with the passing of time; their names are proof of the involvement of our ancestors in preserving the Byzantine tradition and of their solid musical training.

The catalogue complies with the codicological standards, being a useful tool for the researchers interested in the music preserved in the manuscripts of Byzantine tradition. Concurrently, the book is a plentiful source of interesting information in respect to the history of church music - for psalm readers, copyists, psalmic music composers -, as well as for the history of monachism providing data related to the life of the Romanian monks and to their connections with Mount Athos. The award given in 2000 by the Union of Romanian Composers and Musicologists highlighted, once more, the significance of the book.

\section{Restitutions from the Romanian psalmic creation of the $19^{\text {th }}$ century: Ghelasie Basarabeanu}

Two centuries back, Ghelasie (?-1855) - also called by the people the "one from Bessarabia” or the Archimandrite ${ }^{15}$ - was settling in Curtea de Argeș as main chanter with the Episcopal Church. His name was associated for a long time only with the Doxology in the $5^{\text {th }}$ mode - which is still sung sometimes in the end of the morning service - because none of his creations were printed during his life. Research conducted by priest Ion Isăroiu during his PhD study programme under the supervision of the Archdeacon Sebastian Barbu-Bucur revealed the significance of this main chanter, composer and cantor of church music in respect to the promotion of chants in the Romanian language. He also transcribed in the new notation system a wide psalmic repertoire; he had a significant teaching activity as well with the "Neagoe Basarab" theological seminary of Curtea de Argeș where he taught in the period 1838-1851. Most of the chants transcribed into musical notes were meant for his pupils, as the mention accompanying the title reveals: "to be of use to the Seminary of Argeș" (Ionescu, 2003, p. 112).

Together with his mentor, Father Ion Isăroiu tracked down over 60 manuscripts which mention the chants that Ghelasie's pupils would learn from their teacher. Out of these manuscripts, Professor Sebastian Barbu-Bucur PhD

\footnotetext{
15 The "one from Bessarabia” cognomen points to his Moldavian origins, the principality being located on the eastern side of the river Prut. The name of "Bessarabia" was given by the Russian Empire to the territory bordered by the rivers Prut and Dniester, a territory which was ceded to Russia by the Treaty of Bucharest from 1812, at the end of the Russo-Turkish war. (1806-1812).
} 
and Ion Isăroiu $\mathrm{PhD}$ collected and edited for print four chant volumes transliterated, verified, improved and transcribed in staff line notation - thus trying to make the most of the chant repertoire transposed in Romanian by the great psalm reader. The volumes were published between 2004-2007 by the Musical Publishing House from Bucharest being part of the prestigious collection Sources of Romanian Music, accounting for over 2000 pages (S. Barbu-Bucur, 2004, 2005, 2006, 2007).

The transcription on staff as well as the chant analysis highlighted Ghelasie's talent and skill to achieve a fluent and expressive melodic line perfectly congruent with the religious text. Due to the above mentioned qualities, the authors of the anthologies called Ghelasie a "classic of the Romanian music of Byzantine tradition" situating him in terms of significance of his work side by side with his contemporaries, Macarie the Hieromonk and Anton Pann.

The complete publishing of Ghelasie's work opens new perspectives for the investigation of his musical input and of the adaptations to the Romanian language of a repertoire originating in Greek sources. The merit rests with the two editors for having gathered and structured the musical material spread throughout tens of manuscripts. Rendered in both notations (neumatic and on staff), the chants give musicologists the opportunity for thorough analysis as well as for assessing the place of the modest psalm reader among the personalities who had a critical contribution to the generalization of church chant in the Romanian language in the first half of the $19^{\text {th }}$ century.

\section{New data regarding the Romanianisation process of church chant in the 18th century: Mihalache Moldovlahul's [the Moldavian-Wallachian] Anastasimatarion}

For the tireless researcher Sebastian Barbu-Bucur the process of Romanianisation of choir chant represented an ongoing concern until his last years of activity. In his monumental accomplishment represented by the analysis of Filothei Jipa's Romanian Psalm Book, the illustrious hermit set the main historical coordinates of this process considering that it unfolded in four stages (Barbu-Bucur, 1989, p. 95) ${ }^{16}$. Over the years he tried to find all the musical documents attesting the continuity of this process and insisted

\footnotetext{
${ }^{16}$ The stages are as follows: 1 ) starting with the emergence of the creations on Romanian texts until the end of the 18th century (the transmission of the chant would have taken place by "word of mouth, as it was not written with neumes"; 2) from the last decades of the $17^{\text {th }}$ century until 1814; 3) the first half of the $19^{\text {th }}$ century, Macarie's and Anton Pann's translations; 4) the second half of the 19th century and the first part of the next, "from Dimitrie Suceveanu, Neagu Ionescu, Ștefanache Popescu etc., up to Popescu-Pasărea, the last one who had a say in regards to the Romanianisation process of church chant” (Barbu-Bucur, 1989, p. 95).
} 
especially on the second stage (starting with the late decades of the $17^{\text {th }}$ century up to the 1814 Reform). The sequence of the documents lacked a link: the first manuscript in which music is written down directly on the Romanian text. The writings of the $19^{\text {th }}$ century (Hieromonk Macarie and Anton Pann) pointed to the name Mihalache Moldoveanul [the Moldavian] or Moldovlahul [the Moldavian - Wallachian], author of an Anastasimatar around the year 1767 (according to Anton Pann), mentioned by Father Sebastian for the first time in a study dating back to 1976 (Barbu-Bucur, 1976). In 1982 in the Great Lavra Library (Athos), the priest was given the opportunity to discover the manuscript of the Anastasimatar with the call number Z 26 which he considered to be the original one elaborated by Mihalache.

The study of Mihalache's contribution to the process of Romanianisation of church chant went on and further information was added to it due to the increased interest towards the psalm reader's creation. Two of his manuscripts were discovered in the following years by priest Alexie Al. Buzera $\mathrm{PhD}$ (1999) and priest Florin Bucescu PhD (2000) ${ }^{17}$. In the year 2008 the series of restitutions from the creation of the Romanian psalm readers was made whole by Father Sebastian with a first volume of Mihalache Moldovlahul's Anastasimatarion (Barbu-Bucur, 2008), published in the Sources of Romanian Music collection of the Musical Publishing House. Two more will follow: in 2011, the second part of the Anastasimatarion comprising the chants in the plagal modes (S. Barbu-Bucur, 2011) and two years later a volume with 30 more chants signed by Mihalache (Barbu-Bucur, 2013 a).

Due to Father's Sebastian tireless and perseverant work new data was added to the scarce existent information related to this psalm reader, mentioned by different names - Mihalache Moldoveanu [the Moldavian], Mihail Iftimivici, Mihalache Ieşeanul [from Iaşi] - and numerous manuscripts were discovered comprising the psalm reader's chants a well as and notes in his regard. The introductory studies of the three volumes dedicated to Mihalache include, along with the codicological description of the manuscripts, the incipits of various chants, examples with contrastive versions of different formulas from various manuscripts, considerations regarding the Greek source of the chants and other adjacent information drawn from archive documents and personal opinions argued and sustained in a convincing manner.

Therefore - as monk Filotheu Bălan observed -, for the time being "the merit rests with archdeacon Sebastian Barbu-Bucur for having written the first

\footnotetext{
17 Priest Alexie Buzera discovered the manuscript no. 4556, Anastasimatar at the National Library of Romania of Bucharest (Buzera, 1999, p. 178), while priest Florin Bucescu the manuscript entitled Octoih, at the Dumbravele Monastery from the county of Neamț (Bucescu, 2002, pp. 568-570).
} 
thorough study about Mihalache in the prefaces of the two volumes of Mihalache's Book of Hymns at the Lord's Resurrection” (Bălan, 2013).

The volumes dedicated to Mihalache have led the way towards new perspectives for research, similarly to other Father Sebastian's writings, and the debates regarding the role the psalm reader played in the perpetuation of the Romanianisation process of church chants still continues. Even back in 2013, monk Filotheu Bălan would note several observations and questions regarding this psalm reader; he also questioned - based on viable arguments - the year of the elaboration of the manuscript from the Great Lavra, which he considered a copy. He concluded that "Mihalache Moldoveanu [the Moldavian] is one of the least known composers and Romanian translators of the end of the $18^{\text {th }}$ century” (Bălan, 2013). Hence, the chapter dedicated to psalmic music accompanied by text in Romanian dating from the end of the $18^{\text {th }}$ century remains open to investigation.

\section{Conclusions}

For those who knew him closely, Father Sebastian was always a genuine role model of the researcher - passionate, inquisitive, perseverant, interested in deciphering the ancient notation, in understanding the sequence of events, in finding out the source, the author or the smallest details related to the content and notation of a musical manuscript. For those who are acquainted only with his over 80 studies, 15 books he published or with his abundant creation of services for Romanian saints and other church chants, he will still represent for a long time the most significant documentary source in respect to what he himself called "the process of Romanianisation of church chant". His constant concern to delineate the Romanian contribution to the preservation and transmission of the Byzantine creation is significantly emphasised by the last book he signed, the anniversary volume celebrating 300 years from the conclusion of Filothei Jipa's manuscript. Entitled Romanian Treasure of Byzantine Tradition. The period unfolding between the 18th and the 21st century, the volume reunites the author's main research topics and reiterates several of his previous studies and articles (Barbu-Bucur, $2013 \mathrm{~b}$ ).

This study aimed only at some of the volumes published by the Archdeacon Sebastian Barbu-Bucur but, looking at things in perspective, his entire activity focuses around the same "red thread" represented by the Romanianisation of church chant, even though he wove together various interests and different research topics during his life. Focusing especially on the $18^{\text {th }}$ century, his research resulted in several notable contributions for the knowledge of the byzantine musical tradition across the Romanian territory, of which we mention: his emphasis on the value of one of the oldest church music manuscripts accompanied by text in Romanian as well as stressing the value of its author, Filothei Jipa; the setting of the main coordinates for the 
Romanianisation process of the church choir chant; the restitution by means of publication in documenta and transcripta versions of Mihalache Moldoveanu's and Bessarabian Ghelasie's musical creation, almost unknown until his research; the focus on the presence of Romanian psalm readers at Mount Athos as well as the elaboration of the first catalogue of the manuscripts to be found in seven different monasteries from Mount Athos. The results of his research were also mirrored by his abundant creation of psalmic music with Romanian features as well as in numerous concerts and recordings with Romanian psalmic music brought to life by the Psalmodia Band of Byzantine Music which he founded in 1988 and conducted for over two decades.

Archdeacon Sebastian Barbu-Bucur's tireless work as a researcher of Byzantine music contributes to a better knowledge and understanding of the evolution of this music in the $18^{\text {th }}$ and the $19^{\text {th }}$ century and leads the way towards the premises for new investigations in the years to come.

\section{References}

Barbu-Bucur, S. (1976). Manuscrise psaltice românești și bilingve în notaţie cucuzeliană [Romanian and bilignual psaltic manuscripts in Cucuzel's notation]. Studii de muzicologie, XII, 175-229. București: Editura Muzicală.

Barbu-Bucur, S. (1981). Filothei sin Agăi Jipei, Psaltichie rumănească [The Romanian Psalm Book]. vol. I. Catavasier. Sources of Romanian Music - Documenta et transcripta. vol. VII A. București: Editura Muzicală.

Barbu-Bucur, S. (1984). Filothei sin Agăi Jipei. Psaltichie rumănească [The Romanian Psalm Book]. vol. II. Anastasimatar. Sources of Romanian Music Documenta et transcripta, vol. VII B. București: Editura Muzicală.

Barbu-Bucur, S. (1987). Filothei sin Agăi Jipei. Psaltichie rumănească [The Romanian Psalm Book]. vol. III. Stihirariul. Sources of Romanian Music - Documenta et transcripta, vol. VII C. București: Editura Muzicală.

Barbu-Bucur, S. (1989). Cultura muzicală de tradiție bizantină pe teritoriul României in secolul XVIII şi începutul secolului XIX și aportul original al culturii autohtone, [The musical culture of Byzantine tradition on Romanian territory in the 18th century and the beginning of the 19th century and the original contribution of the autochthonous culture]. București: Editura Muzicală.

Barbu-Bucur, S. (1992). Filothei sin Agăi Jipei. Psaltichie rumănească [The Romanian Psalm Book]. vol. IV. Stihirariu-Penticostar. Sources of Romanian Music Documenta et transcripta, vol. VII D. București: Editura Muzicală.

Barbu-Bucur, S. (2000). Manuscrisele muzicale românești de la Muntele Athos [Romanian musical manuscripts of Mount Athos]. București: Editura Muzicală. 
Barbu-Bucur, S., Isăroiu, I. (2004). Ghelasie Basarabeanu, Vecernier și Utrenier [Ghelasie Basarabeanu at Vespers and Matins]. Sources of Romanian Music Documenta et transcripta, vol. XI A. București: Editura Muzicală.

Barbu-Bucur, S., Isăroiu, I. (2005). Ghelasie Basarabeanu, Liturghier [Ghelasie Basarabeanu, Liturgy]. Sources of Romanian Music - Documenta et transcripta, vol. XI B. București: Editura Muzicală.

Barbu-Bucur, S., Isăroiu, I. (2006). Ghelasie Basarabeanu, Doxastar. Sources of Romanian Music - Documenta et transcripta, vol. XI C, București: Editura Muzicală.

Barbu-Bucur, S., Isăroiu, I. (2007). Ghelasie Basarabeanu, Doxastar, Triod, Penticostar. Sources of Romanian Music - Documenta et transcripta, vol. XI C. București: Editura Muzicală.

Barbu-Bucur, S. (2008). Mihalache Moldovlahul I, Anastasimatar. Sources of Romanian Music - Documenta et transcripta, vol. XII A. București: Editura Muzicală.

Barbu-Bucur, S. (2011). Mihalache Moldovlahul II, Anastasimatar, Sources of Romanian Music - Documenta et transcripta, vol. XII B. București: Editura Muzicală.

Barbu-Bucur, S. (2013 a). Mihalache Moldovlahul III, Muzică bizantină în veșmânt românesc. Sec. XVIII [The Byzantine music in Romania]. Sources of Romanian Music - Documenta et transcripta, vol. XII C. București: Editura Muzicală.

Barbu-Bucur, S. (2013 b). Tezaur de muzică bizantină pe teritoriul României - sec. XVIII-XX (1713-2013) [Treasury of Byzantine music in Romania]. București: Editura SemnE.

Bălan, F. (2013). Creația muzicală a lui Mihalache Moldoveanul [The musical creation of Mihalache Moldoveanul] http://www.byzantion.ro/articole/item/178creatia-muzicala-a-lui-mihalache-moldoveanu.html, accessed on 10.04.2016.

Bucescu, Fl. (1997). Sebastian Barbu-Bucur și restituirea „Psaltichiei rumănești” [Sebastian Barbu-Bucur and the restitution of the Romanian Psalm Book]. Muzica, 2, 149-154. București: Editura Muzicală.

Bucescu, Fl. (2002). Cântarea psaltică în manuscrisele moldovenești din secolul al XIX-lea. Ghidul manuscriselor - Moldova sec. XIX [The psaltic chant in Moldavian manuscripts from the 19th century. The guide of the manuscripts - Moldova, 19th century]. vol. 1-2. Iaşi: Artes.

Buzera, A. Al., (1999). Cultura muzicală de tradiție bizantină din sec. al XIX-lea [Musical culture of Byzantine tradition from the 19th century]. Craiova: Editura Scrisul românesc.

Catrina, C. (2005, editor). Sebastian Barbu-Bucur, 75 de ani [Sebastian Barbu-Bucur, 75 years old]. București: Editura SemnE.

Catrina, C (2010, editor). Sebastian Barbu-Bucur, octogenar [Sebastian Barbu-Bucur, octogenary]. București: Editura SemnE. 
Chircev, E. (2005 a). Arhid. Dr. Sebastian Barbu-Bucur - Destăinuiri la 75 de ani [Archimandrite $\mathrm{PhD}$ Sebastian Barbu-Bucur - Confessions at 75 years old]. Renașterea, 2 (180). Cluj-Napoca: Editura Renașterea.

Chircev, E. (2005 b). Restituiri la Editura Muzicală: Ghelasie Basarabeanu „Vecernier şi Utrenier” [Restitutions at the Musical Publishing House: Ghelasie Basarabeanu at Vespers and Matins]. Renaşterea, 5 (183). Cluj-Napoca: Editura Renaşterea.

Chircev, E. (2005 c). Moment de omagiere a bizantinologiei româneşti la Cluj-Napoca [Homagial moment of the Romanian Byzantinology at Cluj-Napoca]. Renașterea, 5 (184). Cluj-Napoca: Editura Renașterea.

Chircev, E. (2006). Eveniment editorial: „Liturghierul” lui Ghelasie Basarabeanu [Literary event: Ghelasie Basarabeanu's Book of Liturgy]. Renașterea, 3 (191). ClujNapoca: Editura Renașterea.

Chircev, E. (2013). Laudatio pentru arhid. prof. univ. dr. Sebastian Barbu-Bucur [Laudatio for Archidiacon PhD Professor Sebastian Barbu-Bucur]. Mărturii și dialoguri despre muzica bizantină [Confessions and Dialogues about the Byzantine music] (pp. 104-109). Cluj-Napoca: Editura Risoprint.

Cosma, V. (1990). Emoționantă întâlnire cu muzica de tradiție bizantină [An emotional encounter with the Byzantine music]. Libertatea, 97 (17th of, 3. Bucharest.

Ionescu, Gh. C. (2003), Muzica bizantină în România. Dicționar cronologic, [The Byzantine music in Romania. Chronological dictionary] (pp. 447-483). București: Sagittarius. 